$\frac{52}{7-2} 29395(3)$

PPPL-2924

UC-420,426
PREPARED FOR THE U.S. DEPARTMENT OF ENERGY, UNDER CONTRACT DE-AC02-76-CHO-3073

PPPL-2924

LOWER HYBRID WAVE COUPLING IN PBX-M

BY

R.E. BELL, S. BERNABEI, N. GREENOUGH, ET AL.

JULY, 1993

pqINCETON

plabma puraice

LABofatoar

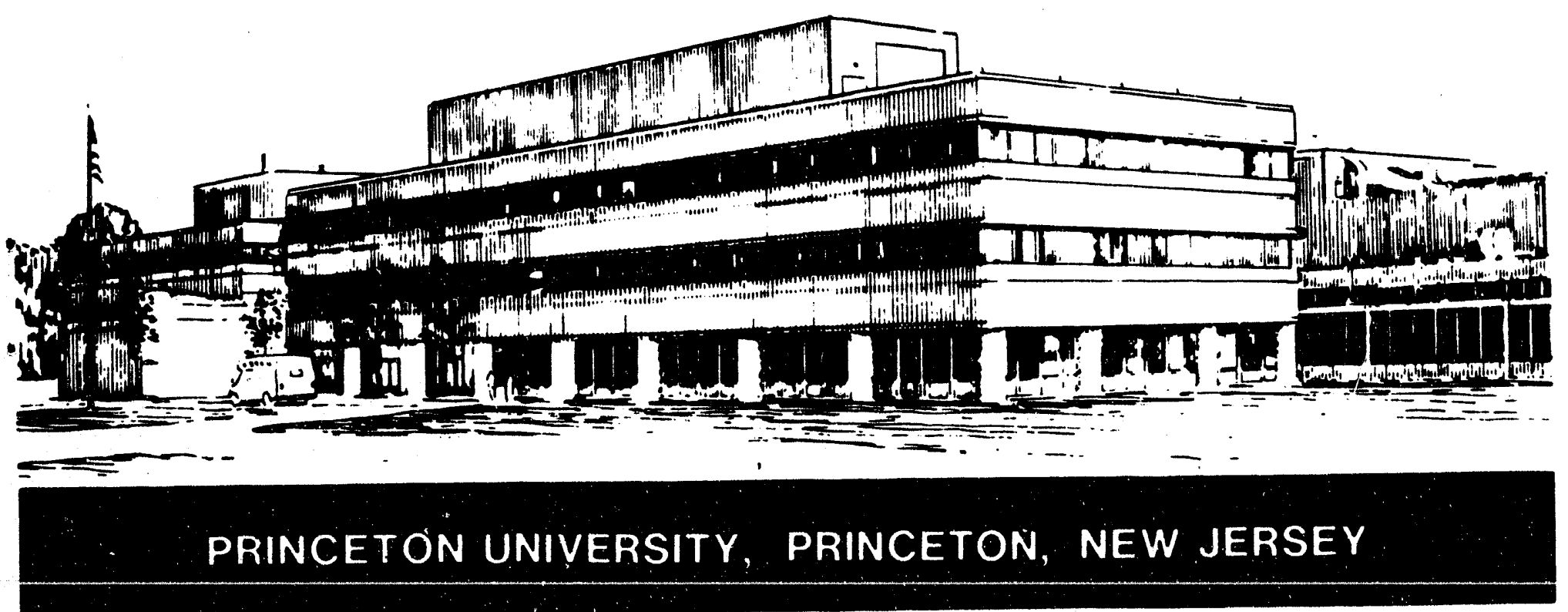




\section{NOTICE}

This report was prepared as an account of work sponsored by an agency of the United States Government. Neither the United States Government nor any agency thereof, nor any of their employees, makes any warranty, express or implied, or assumes any legal liability or responsibility for the accuracy, completeness, or usefulness of any information, apparatus, product, or process disclosed, or represents that its use would not infringe privately owned rights. Reference herein to any specific commercial produce, process, or service by trade name, trademark, manufacturer, or otherwise, does not necessarily constitute or imply its endorsement, recommendation, or favoring by the United States Government or any agency thereof. The views and opinions of authors expressed herein do not necessarily state or reflect those of the United States Government or any agency thereof.

\section{NOTICE}

This report has been reproduced from the best available copy.

Available in paper copy and microfiche.

Number of pages in this report: 17

DOE and.DOE contractors can obtain copies of this report from:

Office of Scientific and Technical Information

P.O. Box 62

Oak Ridge, TN 37831;

(615) 576-8401.

This report is publicly available from the:

National Technical Information Service

Department of Commerce

5285 Port Royal Road

Springfield, Virginia 22161

(703) $487-4650$ 


\title{
LOWER HYBRID WAVE COUPLING IN PBX-M
}

\author{
R. E. BELL, S. BERNABEI, N. GREENOUGH, L. LAGIN, B. LEBLANC, \\ M. OKABAYASHI, H. TAKAHASHI \\ (Princeton Plasma Physics Laboratory, Princeton University, P.O. Box 451, \\ Princeton, New Jersey, United States of America) \\ L. SCHMITZ, L. BLUSH, R. DOERNER, G. TYNAN, R. W. CONN \\ (Institute of Plasma and Fusion Research, University of Califormia at Los Angeles, \\ Los Angeles, California, United States of America) \\ S. LUCKHARDT \\ (Plasma Fusion Center, Massachusetts Institute of Technology, Cambridge, \\ Massachusetts, United States of America)
}

\begin{abstract}
The coupling of the waves launched from a $4.6 \mathrm{GHz}$ lower hybrid system into PBX-M plasmas has been studied for both L-mode and H-mode plasmas. The characteristics of the plasma in front of the LH coupler have been measured with a fast Langmuir probe. The reflected power of the coupler has been measured across the transition to H-mode as a function of phase and the distance between the coupler and the separatrix. A transient rise in the $\mathrm{LH}$ reflection coefficient was observed near the L-H transition under some conditions. Coupling depends primarily on the electron density in the vicinity of the coupler, and proper positioning of the coupler can compensate for changes in the plasma edge due to H-mode transitions. Good coupling can be maintained throughout the H-mode.
\end{abstract}

\section{INTRODUCTION}

The coupling of lower hybrid ( $\mathrm{LH}$ ) waves between the plasma and a multi-waveguide grill has been described using a linear theory $[1,2]$ which has agreed well with experiment. It has been shown that the electron density of the plasma and the density gradient in the immediate vicinity of the grill are the determining factors for coupling. When a plasma undergoes a transition from an L-mode regime to an 
$\mathrm{H}$-mode regime, there is a dramatic change in the edge conditions of the plasma. $\mathrm{LH}$ experiments during $\mathrm{H}$-modes have been conducted on several machines $[3,4,5]$. A lower hybrid grill operating between these two regimes is potentially subject to a change in coupling that could not only diminish the net forward power, but increase the power reflected back into the waveguides which might in turn lead to arcing if sufficiently high.

Lower hybrid waves are being used on the PBX-M tokamak [6] for current density profile modification to optimize confinement and to control instabilities. Here, the coupling of LH waves in PBX-M is examined and compared to Brambilla theory [1]. The launched LH spectrum and the relative plasma to coupler position has been varied. The edge plasma has also characterized with a fast Langmuir probe in both L-mode and H-mode plasmas.

The lower hybrid (LH) system on PBX-M [7] was operated at a frequency of $4.6 \mathrm{GHz}$. The coupler used in these experiments was made up of 32 waveguides, each $6 \mathrm{~cm}$ high $\times 0.5 \mathrm{~cm}$ wide. The coupler was located $8.7 \mathrm{~cm}$ below the midplane and was curved in two dimensions to approximate the edge contours of the plasma. The coupler could be manually positioned between discharges over a range of a few $\mathrm{cm}$ along the major radius. The phase of each waveguide could be individually adjusted during the LH pulse (at a rate of $20 \% \mathrm{~ms}$ ). By adjusting the relative phases $(\Delta \emptyset)$ of the 32 waveguides, the parallel refractive index, $n_{\|}=c k_{\|} / \omega$, could be varied up to $n_{\|}=4.2$ with $\Delta \emptyset=180^{\circ}$ $\left(n_{\|}=4.2 \Delta \emptyset / 180^{\circ}\right)$. The reflected powers of each waveguide were measured near the plasma interface; summing these gave the total reflected power $\left(P_{R E F}\right)$. The total forward power $\left(P_{F W D}=P_{L H}\right)$ was measured just before the phase shifters. Under conditions of good coupling, a reflection coefficient $R\left(\equiv P_{R E F} / P_{F W D}\right) \leq 10 \%$ was measured.

\section{COUPLING CALCULATIONS}

The coupling calculations are based on Brambilla theory [1]. The Stevens code [2] is used which includes the possibility of a vacuum gap $\left(x_{p}\right)$ between the grill and the plasma and a non-zero density near the grill $\left(n_{0}\right)$ followed by the usual linear ramp 
with a gradient $\nabla \mathrm{n}$. The vacuum gap is a region is which the electron density is below the cut-off density, $\mathrm{n}_{\mathrm{co}}$. The cut-off density occurs where the operating frequency is equal to the local electron plasma frequency $\left(n_{c o}=m_{e} \omega^{2} / 4 \pi e^{2}\right) ;$ at $\omega / 2 \pi=4.6 \mathrm{GHz}, n_{c o}=$ $2.6 \times 10^{17} \mathrm{~m}^{-3}$.

Figure 1a shows the forward and reflected power for $\mathrm{LH}$ waves launched into a circular hydrogen plasma with a plasma current $I_{p}=130 \mathrm{kA}$ and $P_{F W D}=180 \mathrm{~kW}$. As $\Delta \emptyset$ was varied between $180^{\circ}$ and $-30^{\circ}$, the reflected power changed showing a minimum reflection between $\Delta \emptyset=-75^{\circ}$ and $\Delta \emptyset=-90^{\circ}\left(\left|\mathrm{n}_{\|}\right| \approx 2\right)$. The minus sign indicates waves phased to drive current. The minimum reflection is expected to occur when $\mathrm{n}_{0} \approx \mathrm{n}_{\mathrm{co}} \mathrm{n}_{\|\|^{2}}$ [2], yielding in this case $\mathrm{n}_{0} \approx 10^{18} \mathrm{~m}^{-3}$. Using the Stevens code, a reasonable fit can be obtained (Fig. $1 \mathrm{~b}$ ) assuming $\mathrm{n}_{0}=2.3 \times 10^{18} \mathrm{~m}^{-3}, \nabla \mathrm{n}=1 \times 10^{20} \mathrm{~m}^{-4}$, and $\mathrm{x}_{\mathrm{p}}=$ $1 \mathrm{~mm}$. The measured reflection coefficient deviates from the fit for $|\Delta \emptyset|<60^{\circ}$ for which much of the $n_{\|}$spectrum is below 1 . Brambilla theory assumes that for $\ln _{\|} \mid<1$, due to inaccessibility, all of the power is reflected back into the waveguides. Assuming the fit is correct, not all of this inaccessible power returned to the waveguides to be measured as reflected power.

The best fit to the data occurs for a non-zero vacuum gap. In ASDEX [8], when protective tiles protruded beyond the grill surface, an increase in reflected power was seen which agreed with coupling calculations if a vacuum gap was assumed. On PBX-M, there are no protruding structures in the grill, so there are two possible explanations for non-zero $x_{p}$ in the fit. The first is that there was a slight misalignment of the grill causing some shadowing in front of the waveguides. Alternatively, if some power was reflected in the waveguide structure between the measurement position and the plasma, the higher reflection would be interpreted as a non-zero vacuum gap when choosing a fit. A larger vacuum gap corresponds to a higher reflection, the amount of increase depends on the phasing of the watveguides. Although the fitted values are reasonable for this plasma, no edge density measurements were available at the time these data were measured. 


\section{COUPLING TO H-MODE PLASMAS}

Experiments were performed to examine the coupling of LH waves during L-mode and $\mathrm{H}$-mode plasmas. A typical discharge is shown in Fig. 2. These deuterium plasmas had an indentation of $13 \%$, an ellipticity of $1.7, \mathrm{I}_{\mathrm{p}}=250 \mathrm{kA}$, neutral beam injected power $\mathrm{P}_{\mathrm{NB}}=2 \mathrm{MW}$, and launched $\mathrm{LH}$ power of $\mathrm{P}_{\mathrm{FWD}}=250 \mathrm{~kW}$. A transition from L-mode to $\mathrm{H}$-mode at $0.44 \mathrm{sec}$ is clearly indicated by the drop in the $\mathrm{D}_{\alpha}$ signal and the increase in the rate of rise of the electron density. The line-averaged electron density was $\bar{n}_{e}=2.5 \times 10^{19} \mathrm{~m}^{-3}$ during L-mode, and up to $5.5 \times 10^{19} \mathrm{~m}^{-3}$ durirg H-mode.

Depending on the phasing of the waveguide and the relative plasma to waveguide spacing, a transient rise in the reflected power was measured at the L-H transition. Shown in Fig. 2 with $\Delta \emptyset=-75^{\circ}$, there was a sharp rise in the reflected power as the $\mathrm{H}$-mode began, and though the $\mathrm{H}$-mode continued for $210 \mathrm{~ms}$, the reflected power returned to the L-mode level within $100 \mathrm{~ms}$. This transitory nature of the coupling change corresponded to a change in the edge electron density during the H-mode. There is a strong correlation of the reflected LH power and the reciprocals of the $D_{\alpha}$ signal and the square root of the edge soft $x$-ray signal $\left(S_{x}{ }^{-1 / 2}\right)$. Since both the $D_{\alpha}$ and $\mathrm{S}_{\mathrm{X}}{ }^{-1 / 2}$ scale with electron density, this suggests that the reflected power was increasing due to a drop in the edge density which later recovered as the H-mode continued.

The behavior of the edge plasma was confirmed by fast Langmuir probe measurements. Probe measurements of the edge are shown in Fig. 3 for two similar plasmas. Figure 3a shows the edge electron density just before and just after an L-H transition. Both profiles were taken during the same shot. The L-mode data was measured 12-21 ms before the transition during insertion of the probe. The H-mode data was measured 11-19 $\mathrm{ms}$ after transition during the probe retraction. Edge density for a similar plasma (though a shifted radial location) can be seen in Fig. $3 \mathrm{~b}$ for a time $70-83 \mathrm{~ms}$ after the L-H transition, showing the recovery of the edge density to near L-mode values. At the onset of the H-mode, there was a rapid drop in the edge electron density in the scrape-off region. During the H-mode as the total electron density 
increased, there was a corresponding density increase in the scrape-off region which eventually brought the electron density to levels comparable to those during the L-mode. This recovery of the electron density in the scrape-off region was also seen in plasmas without LH power. The increasing scrape-off density during $\mathrm{H}$-mode tracked the increasing line-averaged electron density. The electron density profiles in the scrape-off region beyond the last closed flux surface for the L-mode, early H-mode and late H-mode seen in Fig. 3 had a decay length of $2 \mathrm{~cm}$.

The electron density at the LH coupler position could also be varied by moving the plasma, with a corresponding change in LH coupling. Two similar discharges are shown in Fig. 4. The approximate position of the $95 \%$ flux surface is shown for the two discharges, indicating the relative edge positions for these plasmas. Indicated with bold lines is a discharge with good coupling through the L-H transition. The coupling was degraded by moving the plasma away from the coupler (by about $1 \mathrm{~cm}$ ) where a sizeable increase in reflected power was seen at the onset of the $\mathrm{H}$-mode.

The reflection during $\mathrm{H}$-mode also varied with the applied phase. For a series of similar discharges, $\Delta \emptyset$ was varied from shot to shot while the coupler plasma separation was constant. Figure 5 shows the reflection coefficient just before and just after the L-H transition. Also shown for some phases is the reflection coefficient late in the $\mathrm{H}$-mode, when the reflection coefficient returned to its L-mode level.

From Fig. 3, the electron density and gradient at the coupler position can be obtained for both the L-mode and H-mode. For L-mode, $\nabla \mathrm{n}=4 \times 10^{19} \mathrm{~m}^{-4}$ and during the early $\mathrm{H}$-mode, $\nabla \mathrm{n}=8 \times 10^{19} \mathrm{~m}^{-4}$. Figure 6 shows the reflection coefficients calculated for this plasma using the Stevens code with gradients of $\nabla \mathrm{n}=1 \times 10^{20} \mathrm{~m}^{-4}$ (solid curve) and $\nabla \mathrm{n}=3 \times 10^{19} \mathrm{~m}^{-4}$ (dashed curve) assuming $\mathrm{x}_{\mathrm{p}}=1 \mathrm{~mm}$. Also shown are the measured densities and reflection coefficients during the L-mode and early $H$-mode times. The reflection coefficient, $R$, during the $H$-mode was taken for the same discharge as the probe measurements. The reflection coefficient during L-mode was measured during the previous discharge. The error bars reflect the uncertainties in measurement of the density and reflected power. There is reasonable agreeinent between the plotted data and the coupling curve. The reciprocal relationship between the reflected power and the density over this density range is evident. There is a only a 
weak dependence of $R$ on $\nabla n$ for values of $n_{0}$ above $4 \times 10^{17} \mathrm{~m}^{-3}$. If the density can be maintained in the region of the shallow part of the curve for this $\Delta \emptyset$ phasing, the reflection coefficient will remain low.

\section{DISCUSSION}

The transient rise in reflected power at the $\mathrm{L}-\mathrm{H}$ transition represents a loss in coupled power to the plasma, and if the overall launched power is high could contribute to arcing in the waveguides resulting in a further loss of power. Good coupling can be retained throughout the $\mathrm{H}$-mode period by maintaining $\mathrm{n}_{0} \geq 10^{18} \mathrm{~m}^{-3}$. To do this across the L-H transition in PBX-M, the coupler must be located quite close (i.e. within millimeters) to the separatrix.

Maintaining the optimal coupling to the plasma depends largely on the density at the lower hybrid grill. The plasma to grill spacing should be adjusted so that the condition $n_{0} \approx n_{c o} n_{\|}{ }^{2}$ is maintained. The optimal density is sensitive to the operating frequency, since the cutoff density is proportional to $\omega^{2}$. The density at the grill depends on the edge density of the plasma and the characteristic decay length in the scrape off region, $\mathrm{n}_{0}=\mathrm{n}_{\text {edge }} \exp \left(-\left(\mathrm{x}_{\text {grill }} \mathbf{-}_{\text {edge }}\right) / \lambda_{n}\right)$. For a given edge density and decay length, a higher operating frequency places a greater demand on the accuracy of the spacing between plasma and grill. Higher operating frequencies lave the advantage of higher density operation with the density limit being approximately proportional to $\omega^{2}$, but with the higher frequency comes the need for a higher edge density for optimal coupling. In PBX-M, the edge density is in the range of $1-2 \times 10^{18} \mathrm{~m}^{-3}$, the density decay length $\lambda_{n} \approx 2 \mathrm{~cm}$, which gives a plasma to grill spacing for optimal coupling of $\approx 0.1-1 \mathrm{~cm}$ for $\mathrm{n}_{\|=2}$ at the operating frequency of $4.6 \mathrm{GHz}$. At a lower frequency this tolerance would be relaxed, at $2.45 \mathrm{GHz}$ for example, a plasma to grill spacing of $\approx 2-6$ $\mathrm{cm}$ would be optimal for $\mathrm{n}_{\|}=2$ with the same edge conditions.

In summary, the coupling on PBX-M can be understood using Brambilla theory. The coupling depends primarily on the electron density at the coupler position. The edge density in the scrape-off layer drops rapidly at the L-H transition and increases to near L-mode levels in about $100 \mathrm{~ms}$ as the overall electron density rises. A transient 
rise in reflected power is observed at the $\mathrm{L}-\mathrm{H}$ transition under some conditions. With proper positioning of the coupler, good coupling can be maintained throughout the H-mode.

\section{ACKNOWLEDGEIMENTS}

This work was supported by the U. S. Department of Energy, Contract No. DE-AC02-76CHO-3073.

\section{REFERENCES}

1. BRAMBILLA, M., Nucl. Fusion 16 (1976) 47.

2. STEVENS, J., ONO, M., HORTON, R., WILSON, J. R., et al., Nucl. Fusion 21 (1981) 1259.

3. TSUJI, S., USHIGUSA, Y., IKEDA, Y., et al., Phys. Rev. Lett. 64 (1990) 1023.

4. SÖLDNER, F. X., BARTIROMO, R., LEUTERER, F., et al., Nucl. Fusion 33 (1993) 333.

5. EKEDAHL, A., BRINKSCHULTE, H., BRUSATI, M., et al., in Radiofrequency Heating and Current Drive of Fusion Devices (Proc. Europhysics Topical Conf. Brussels, 1992) Vol. 16E, European Physical Society (1992) 221.

6. R. E. BELL, N. ASAKURA, S. BERNABEI, et al., Physics Fluids B, 2 (1990) 1271.

7. GREENOUGH, N., BERNABEI, S., NORRIS, M., et al., in Proc. IEEE 14th Symposium on Fusion Engineering (San Diego, 1991) Vol. 1, IEEE (1992) 126.

8. LEUTERER, F., SÖLDNER, F. X., BRAMBILLA, M., et al., Plasma Physics and Controlled Fusion, 33 (1991) 169. 


\section{FIGURE CAPTIONS}

FIG. 1. Reflected LH power versus phase. (a) The forward and reflected power are shown for a circular plasma as $\Delta \emptyset$, the phase difference between waveguides, was varied in time from $180^{\circ}$ to $-30^{\circ}$. (b) The reflection coefficient is plotted versus phase. The dotted line is a fit to the data using the Stevens code and assuming that $\mathrm{n}_{0}=2.3 \times 10^{18} \mathrm{~m}^{-3}, \nabla \mathrm{n}=1 \times 10^{20} \mathrm{~m}^{-4}$, and $\mathrm{x}_{\mathrm{p}}=1 \mathrm{~mm}$.

FIG. 2. Time evolution of a typical H-mode discharge showing line-averaged electron density, $\mathrm{D}_{\alpha}$ emission, injected neutral beam power, and launched $\mathrm{LH}$ power. A transient rise in the reflection coefficient, $R$, can be seen after the $L-H$ transition. There is a correlation between the $\mathrm{LH}$ reflection coefficient and the reciprocal of the square root of the edge soft $\mathbf{x}$-ray signal, $S_{\mathbf{x}}{ }^{-1 / 2}$, and the reciprocal of the $D_{\alpha}$ emission.

FIG. 3. Fast Langmuir probe measurements showing edge electron density. (a) Probe measurements taken just before and just after the L-H transition during the same discharge. (b) Probe measurement during late period of $\mathrm{H}$-mode, $75 \mathrm{~ms}$ after transition, for a similar discharge.

FIG. 4. Time evolution of two similar discharges with shifted radial locations show a different coupling behavior during $\mathrm{H}$-mode. With the plasma closer to the coupler (bold lines), there is almost no change in the coupling across the L-H transition. With the plasma shifted away from the coupler (narrow lines), an increase in reflected power is seen.

FIG. 5. Reflection coefficient versus phase for $\mathrm{H}$-mode plasmas. Plotted are reflection coefficients during L-mode (square), early $\mathrm{H}$-mode (diamond), and late H-mode (circle). For this plasma-to-coupler spacing, the reflection coefficient generally increased at the L-H transition, then returned to near its L-mode value later during the $\mathrm{H}$-mode.

FIG. 6. Comparision of measurement and coupling calculation. The plotted points are the measured reflection coefficients and electron densities at the coupler. The error bars reflect uncertainties in measurement. The solid curve predicts the reflection coefficient for a density gradient of $1 \times 10^{20} \mathrm{~m}^{-4}$, which is near the L-mode gradient shown in Fig. 3. The dashed curve corresponds to a density gra dient of $3 \times 10^{19} \mathrm{~m}^{-4}$, which is near the gradient during the early H-mode period for Fig. 3. Both curves assume a vacuum gap of $1 \mathrm{~mm}$. 

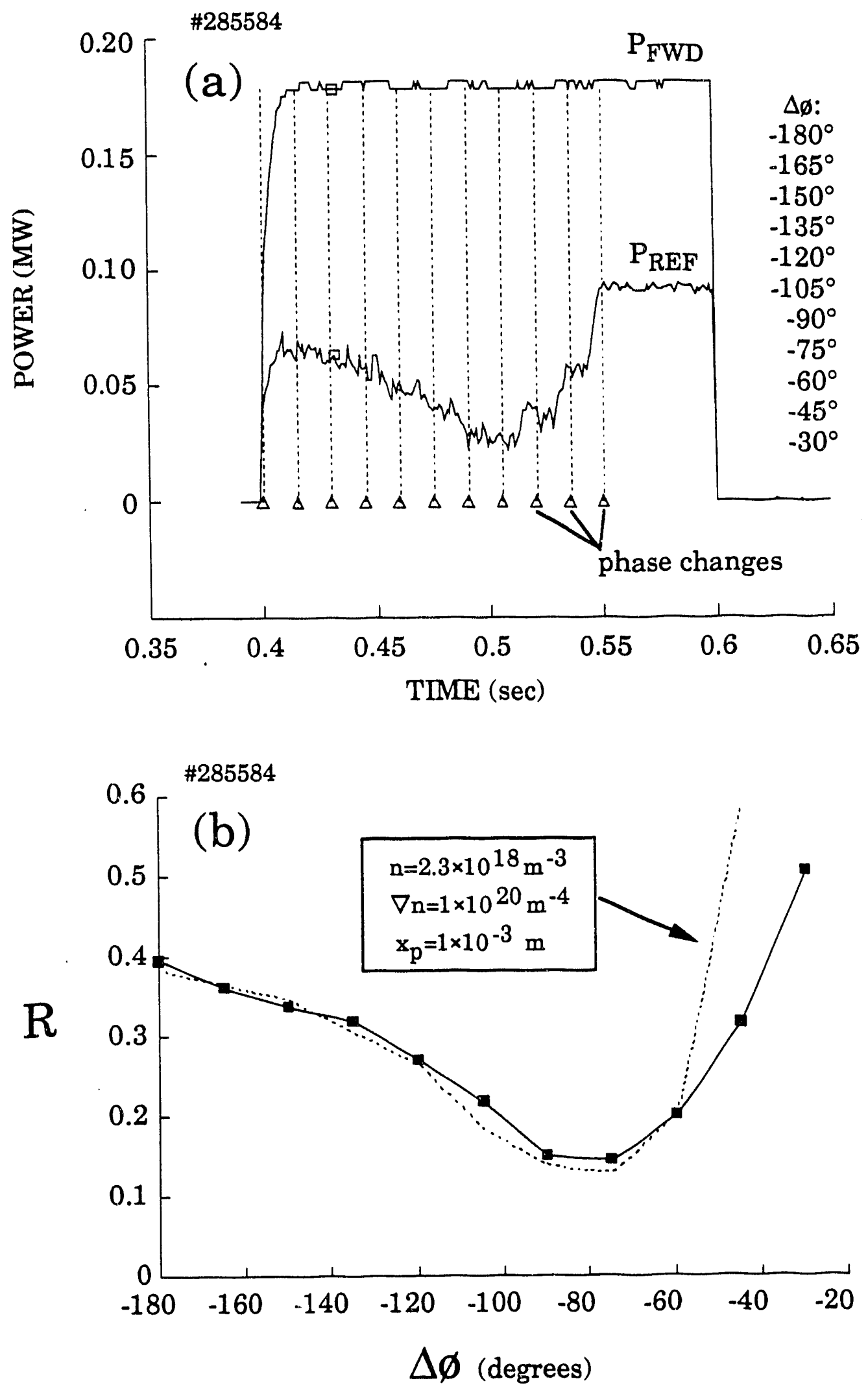

Fig. 1 


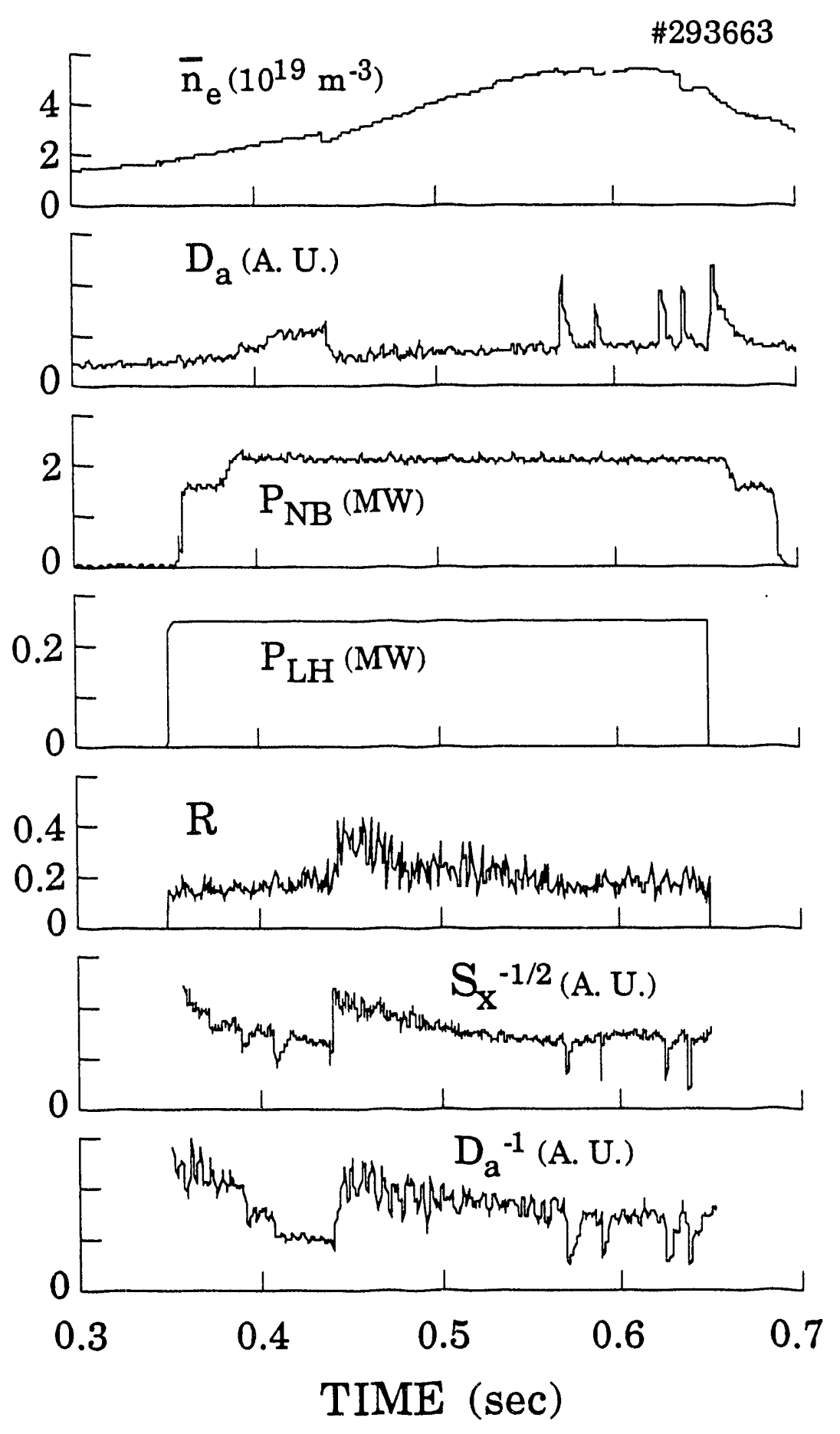

Fig. 2 


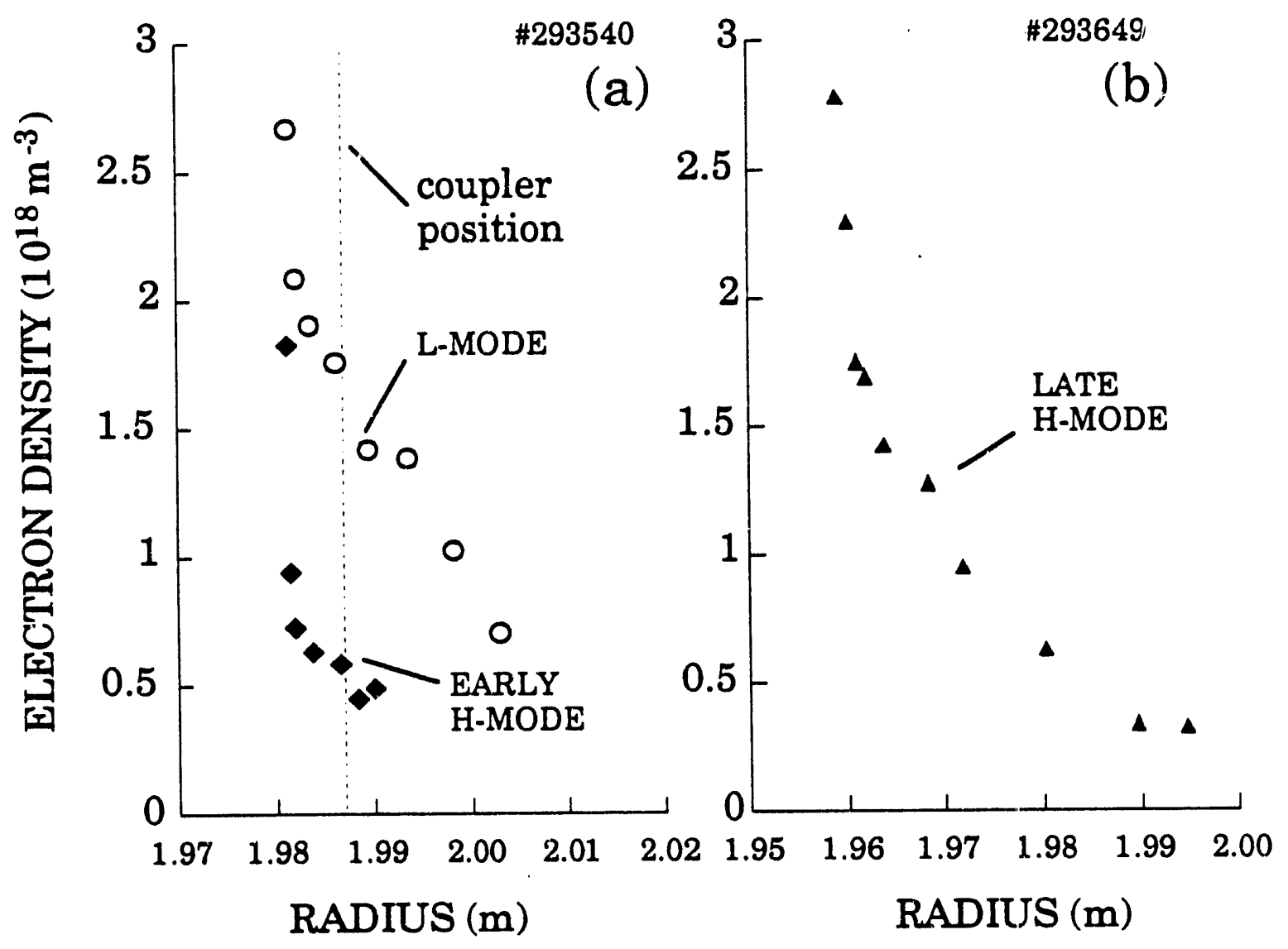

Fig. 3 

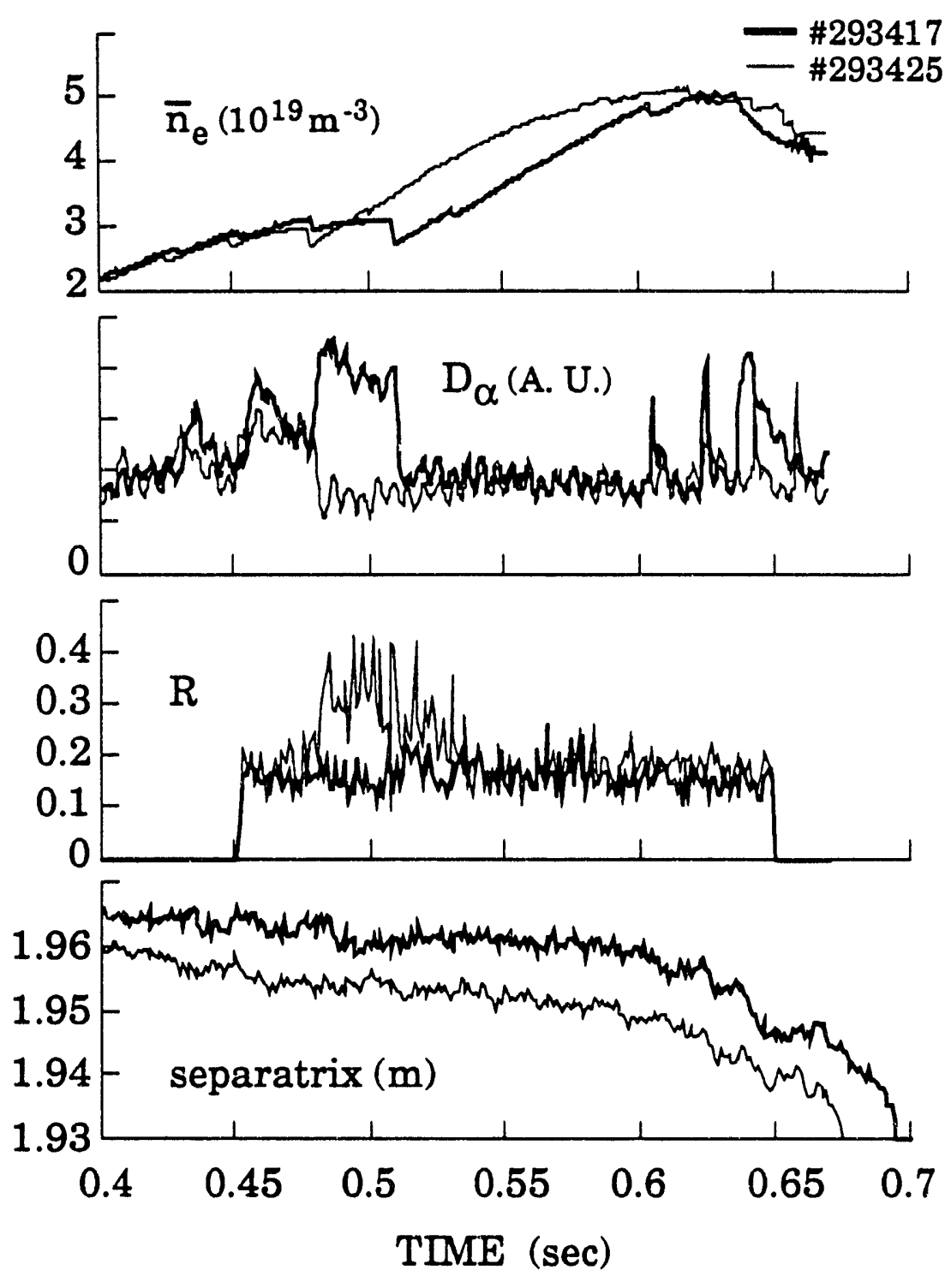

Fig. 4 


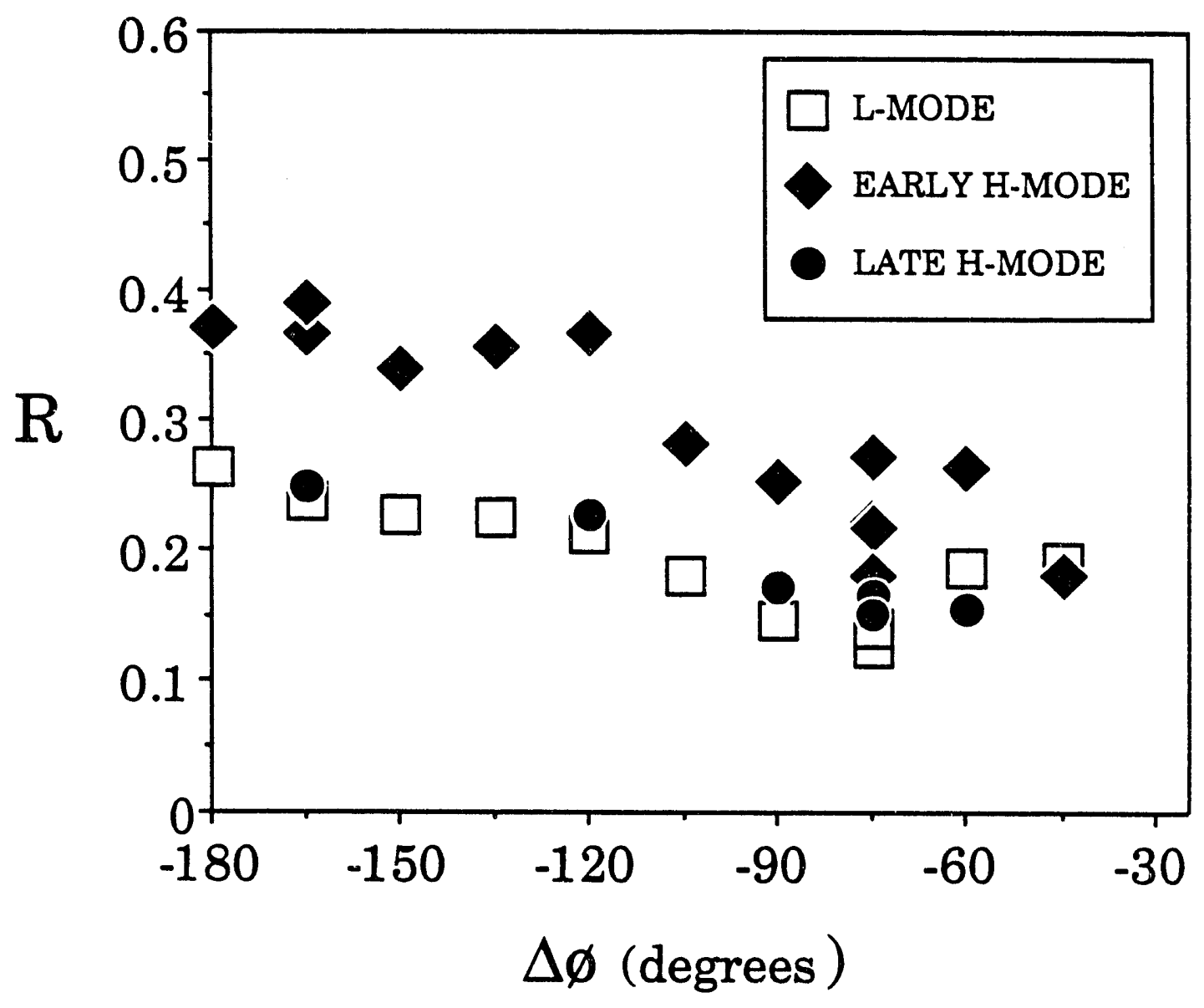

Fig. 5 


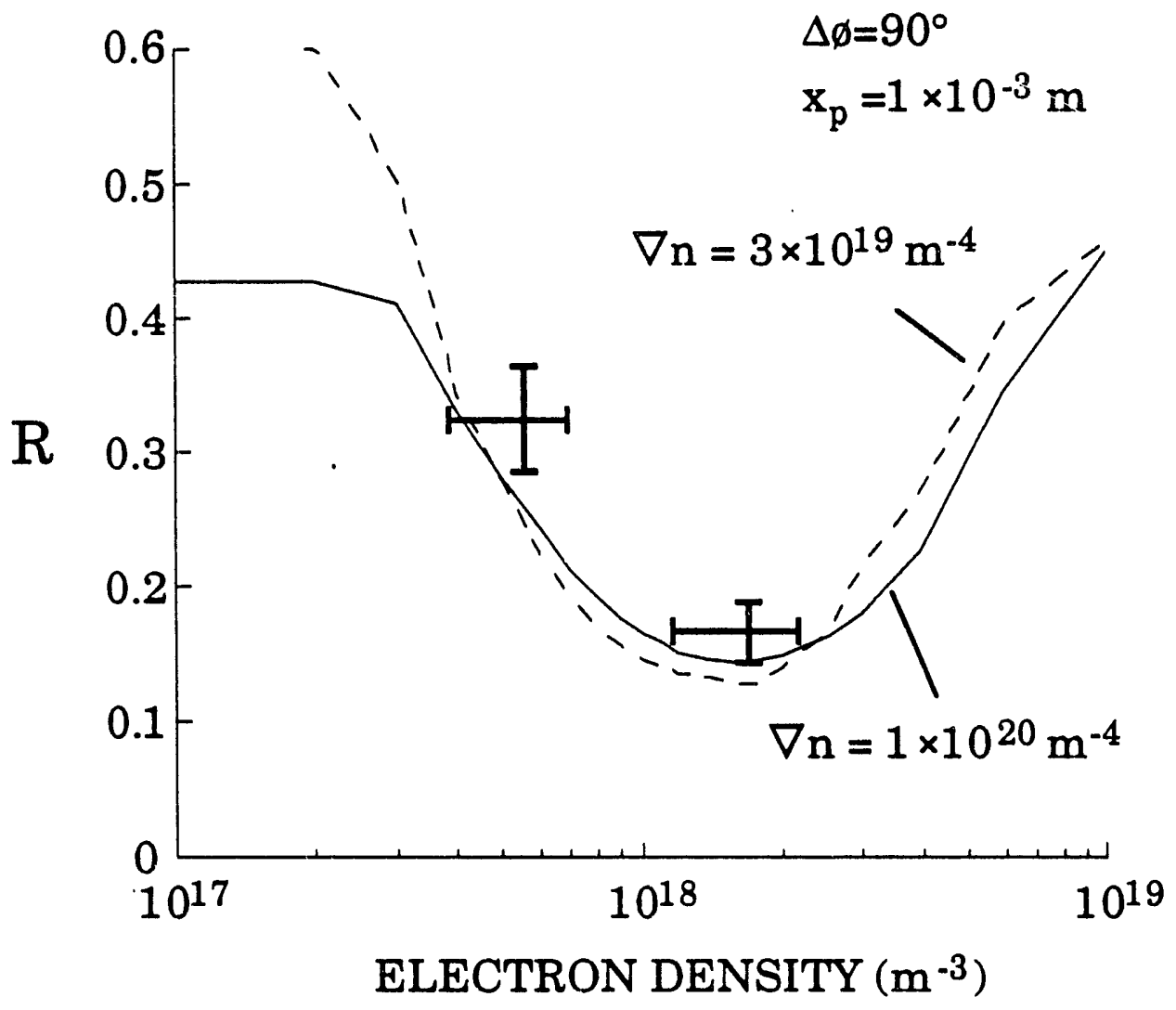

Fig. 6 
Dr. F. Proboni, Univ. of Woltongong, AUSTRALIA

Prof. M.H. Bronnan, Univ. of Sydney, AUSTRALIA

Plasma Research Lab., Australian Nat Univ., AUSTRALIA

Prof. I.R. Jones, Flinders Univ, AUSTRALIA

Prof. F. Cap, Inst for Theoretical Physics, AUSTRIA

Prot. M. Heinuter, Instivi tor Theoretische Physik, AUSTRIA

Prof. M. Goossens, Astronomisch instiuUt, BELGIUM

Ecolo Roydo Mitrire, Lab. do Pry. Plasmas, BELGIUM

Commission-European, DG. XII-Fusion Prog., BELGIUM

Prot. R. Boucique, Rijksuniversibit Genth BELGIUM

Dr. P.H. Sakanaka, Instituto Fisica, BRUZIL

Instouto Neciond Do Pesquieus Espaciair.INPE, BPUZIL

Documents Offico, Alomic Energy of Canada LUd., CANADA

Dr. MP. Bectynakj, MPB Tecthnotogios, Inc.. CANADA

Dr. H.M. Skarsagard, Univ. of Sackatchowen, CANADA

Prof. J. Toictmam, Univ. of Montreal, CANADA

Prot. S.R. Sreenivasen, Univ. of Caggary, CANADA

Prol. T.W. Jothston, INRS-Energie, CANADA

Dr. R. Botton, Contro canadien de tusion magnálique, CANADA

D. C.R. James., Univ. of Aborta, CANADA

Dr. P. Lukbe, Komensketho Universzit, CZECHOSLOVAKIA

The Librarian, Cuham Laborabry, ENGLAND

Libray, A61, Ruthortord Apploton Laboratory, ENGLAND

Mrs. S.A. Huthinson, JET Library, ENGLAND

Dr. S.C. Shema, Univ. of South Pacific, FIJIISLANOS

P. Mathonen, Univ. of Heisinki, FINLAND

Prot. M.N. Bussac, Ecote Polybchnique, FRANCE

C. Nounter, Lab. de Physique des Miliaux lonises, FRANCE

J. Radat, CENCAOARACHE - Bat 506, FRANCE

Prot. E. Economou, Univ. of Crote, GREECE

Ms. C. Rinni, Univ. of loamina, GREECE

Dr. T. Mual, Acadomy Bibliographic Ser., HONG KONG

Preprint Libray, Hungarian Academy of Sci., HUNGARY

Dr. 8. DasGupta, Saha inst of Nuctar Physics, INDIA

Dr. P. Kaw, Inst. for Plasma Rosearch, INDIA

Dr. P. Rosenay, Israel Inst. of Technotogy, ISPAEL Litraian, Intemational Conter for Theo Physics, ITALY Miss C. De Pab, Associazione EURATOHENEA, ITALY

Dr. G. Grosso, Istiulo di Fisica del Plasma, ITALY

Prof. G. Rostangni, Istituto Gas lonizzati Dol Cnr, ITALY

Dr. H. Yamato, Toshiba Ros a Dovol Conbr, JAPAN
Prol. I. Kawakami, Hiroshima Univ., JAPAN

Prot. K. Nishikawa, Hiroshima Univ., JAPAN

Director, Japen Atomic Energy Research Inst, JAPAN

Prot. S. Itoh, Kyushu Univ., JAPAN

Rosearch Into. C8., National Instit for Fusion Science, JAPAN

Prof. S. Tanaka, Kyoto Univ., JAPAN

Library, Kyod Univ., JAPAN

Prot. N. Inow, Univ. of Tokyo, JAPAN

Secrotary, Plesm Section, Eloctrobchnical Lab., JAPAN

S. Mori, Tectnical Advisor, LAERI, LAPAN

Dr. O. Niterai, Kumamoto Inst of Technology, JAPAN

J. Hyoon-Sook, Korea Alomic Enorgy Research Inst, KOREA

D.I. Choi, The Korea Adv. Inst of Sai. \& Tech., KOREA

Prof. 8.S. Liby, Univ. of Waikato, NEW ZEALAND

Inst of Phyrica, Chinese Acad Sa PEOPLE'S REP. OF CHINA

Librery, Inst of Plasme Physics, PEOPLE'S REP. OF CHINA

Tsinghua Univ. Library, PEOPLE'S REPUBLIC OF CHINA

Z L. S.W. Inst Physics, PEOPLE'S REPUBUC OF CHINA

Prol. J.A.C. Cabrad, Instituto Superior Tecrico, PORTUGAL

Dr. O. Potrus, AL I CUZA Univ., ROMANIA

Dr. J. de Villiors, Fusion Studios, AEC, S. AFAICA

Prof. M.A. Hellberg. Univ. of Natal, S. AFAICA

Prof. D.E. Km, Pohang Inst. of Sai. \& Tech., SO. KOAEA

Prof. C.I.E.M.A.T, Fusion Division Library, SPAIN

Dr. L Sionflo, Univ. of UMEA, SWEDEN

Library, Royal Inst. of Tectnology, SWEDEN

Prot. H. Whatmson, Chaimers Univ. of Tech., SWEDEN

Contro Phys. Des Plasmas, Ecole Polytech, SWITZERLAND

Bibliothow, Inst. Voor Plasma-Fysica, THE NETHERLANDS

Asst. Prot. Dr. S. Cakir, Midde East Tech. Univ., TURKEY

Dr. VA. Guktikh, Sai. Res. Inst. Eloctophys.I Apparatus, USSR

Dr. D.D. Ryurov, Siberian Branch of Academy of Sa.. USSR

Dr. G.A. Elisoev, I.V. Kurchator Inst, USSR

Librarien, The Ukr.SSR Academy of Sciences, USSR

Dr. LM. Kovizitimykh, Inst. of General Physics, USSR

Komtorsctungsanlage $\mathrm{GmbH}$, Zentrabibtiothek, W. GERMANY

Bibliothok, Inst. Fur Plasmatorschung, W. GERMANY

Prof. K. Schinder, Rutr-Univer sibat Boctium, W. GERMANY

Dr. F. Wagner, (ASOEX), Max-Planck-Instiout, W. GERMANY

Librarian, Max-Planck-Instiut, W. GERMANY

Prof. R.K. Janev, Inst of Physics, YUGOSLAVIA 
